\title{
Establishing the Current State of Research on Urban Regeneration in Waterfront Cities
}

\author{
Nicolae-Costin Mociu
}

\begin{abstract}
The purpose of this study is to combine two bodies of literature and theory: the first on urban change and coastal regeneration, and the second on the ideas of concerns that influence and shape urban regeneration practice. The goal of this paper is to conduct a review of the pertinent literature on this subject. It will analyze urban change theories as well as the key causes that have shaped transformation over the last few decades. Additionally, it aims to define urban regeneration functionally, to explain its principles and features, and to present a brief history of its growth in Romania. Finally, this work seeks to establish the research niche by examining the evolution of waterfront urban rehabilitation.
\end{abstract}

Keywords - Coast, renewal, urban regeneration, waterfront

\section{INTRODUCTION}

Cityscapes are both a reflection of and a catalyst for the numerous processes that drive physical, social, environmental, and economic change, and they are themselves important drivers of many of these changes [1]. The study of urban transformation is crucial if we are to address urban concerns and maximize the potential of urban environments. Modern urban regeneration has grown into a method for directing the urban transition that is used to guide the development of cities. However, despite the fact that urban regeneration is a well-known occurrence, it is a phenomenon that is still little understood. This is mostly due to the fact that there is no standard form of urban regeneration practice and no single approved source of information [1], which makes it difficult to compare and contrast different approaches.

\section{THE NEED FOR URBAN TRANSFORMATION}

Urban change is inextricably tied to issue and opportunity ideas [1]. This section will examine the primary factors that shaped urban development throughout the preceding decades and contributed to the emergence of the present practice of urban regeneration. Roberts [2] identified five important characteristics influencing and influencing contemporary urban regeneration approach. Among these are physical condition and social reaction, housing and health, social advancement and economic growth, urban sprawl management, and the changing function and character of urban policy. The following parts will explore the case study's major factors. 


\section{sciendo}

128 Ovidius University Annals Series: Civil Engineering, Year 23, 2021

\subsection{Physical condition and social reaction}

The most obvious indication of an urban issue is the area's poor physical state. According to Jeffrey and Pounder [3], the physical state of cities and districts, as well as their urban features, are markers of residents' affluence and confidence. On the other side, run-down neighborhoods and decaying city centers serve as an outward manifestation of poverty and economic decline. Degradation of buildings and services, as well as market inefficiencies in the system of land ownership and governance [1]. Roberts et al. [4] established a relationship between metropolitan regions' physical constraints and the planning system. They believe that in some instances, too ambitious planning initiatives have outgrown their implementation capabilities, resulting in devastation and neglect, while in others, planning has resulted in good developments. The planning system must incorporate a more holistic approach to urban management, which encompasses investment, physical intervention, social action, and strategic planning [4].

\subsection{Social welfare and economic progress}

According to McCarthy [5], providing excellent housing and reducing congestion would not always address the issues connected with urban environments. A third issue that must be considered is the enhancement of economic prosperity. The advancement in transportation infrastructure has contributed to suburban expansion during the urban boom period. Tallon [6] said that this aided the tendency of concentration and centralization. However, Leary and McCarthy [7] emphasized that while this flight to the suburbs was beneficial to the rich, it did not alleviate the problem. The inability to respond to changing trade and infrastructural needs, which Robson [8] deemed part of a restructuring process, has harmed older cities the most.

\subsection{Urban development management}

The rapid growth of the urban population, along with advancements in transportation technology, necessitated an extremely cautious management of urban development, as the people and capital began to flee the metropolitan region in favor of the periphery [6]. Parallel to the counter-urbanization process was the suburbanization trend. Pacione [9] asserts that the process of suburbanization accelerated in the postwar decades, favoring the expansion of cities' periphery at the expense of the city core. Tallon [6] suggested that suburbanization and counter-urbanization are identical and have aided in population dispersal. urban expansion and maximize the utilization of existing land. Additionally, it is critical to offer an immediate push to the urban regeneration phenomena [2].

\subsection{Changing urban policy}

This article represents the reality that responsibility for city development and management has shifted constantly between the federal government, municipal governments, and the private sector. According to Roberts [2] "from postwar rebuilding to the contemporary partnership model, responsibility for urban regeneration has moved in accordance with wider social organization traditions and the dominating forces of political activity." In the 1980s, a government-led urban collaboration took the shape of an urban redevelopment [5]. In the 1990s, there was a modest change toward a more holistic style of thinking and acceptance of a variety of new difficulties and issues, such as acceptance of environmental issues and sustainable development principles [2]. 


\section{URBAN REGENERATION}

Roberts [2] sought to develop a working definition for urban regeneration, stating that in order to do so, it is necessary to identify the main areas of concern and potential future challenges, the most important of which is to ensure that public and private policies are in line with the principles of sustainable development. Hence, Roberts [2] defined urban regeneration as:

"Comprehensive and integrated vision and action that leads to the solution of urban problems and aims to bring about a lasting improvement in the economic, physical, social and environmental status of an area that has undergone change"

Extending the previous definition of urban regeneration, an additional number of principles have been identified by Sykes and Roberts [1]. They stressed that urban regeneration should meet the following characteristics:

- To be based on a detailed analysis of the state of an urban area;

- To aim at the simultaneous adaptation of the physical fabric, the social structure, the economic base and the environmental conditions of an urban area;

- Seek to achieve the goal of simultaneous adaptation by generating and implementing a comprehensive and integrated strategy that addresses problem solving in a balanced, orderly and positive manner;

- Setting clear operational objectives that should, whenever possible, be quantified;

- Ensure that the resulting strategy and implementation programs are developed in accordance with the objectives of sustainable development;

- Making the best use of natural, economic, human and other resources, including land and existing features of the built environment;

- Seek to ensure a balance by the full participation and cooperation of all stakeholders with a legitimate interest in the regeneration of an urban area;

- Recognize the importance of measuring the progress of the strategy in order to achieve the specified objectives and monitoring the changing nature and influence of internal and external forces acting on urban areas; accept the likelihood that the initial implementation programs will be revised in line with the changes that are taking place;

- Admit that the various elements of a strategy may progress at different speeds; this may require the redirection of resources or the provision of additional resources in order to maintain a broad balance between the objectives contained in the urban regeneration scheme and to enable all strategic objectives to be achieved;

When comparing urban regeneration with previous strategies such as urban renewal or redevelopment, it is clear that urban regeneration far exceeds their goals and objectives. The aim of urban regeneration is to achieve long-term, strategic and long-term results.

\subsection{Urban regeneration in Romania}

Romanian towns must place a greater emphasis on the rehabilitation of historic districts, since they symbolize the country's historical and cultural legacy. Additionally, the condition of residential areas (with a particular emphasis on block communities) must be improved concurrently with the restoration of public places such as markets, parks, and street furniture. Not to be overlooked is urban infrastructure, which requires modernization initiatives to bring it up to European standards. To accomplish these aims, urban planning must be holistic, recognizing the relevance of several aspects and players on the urban landscape. The national government's role is to support local governments' activities by creating an adequate legal framework and a more effective urban planning system to 


\section{sciendo}

130 Ovidius University Annals Series: Civil Engineering, Year 23, 2021

accomplish all goals. Urban regeneration should prioritize several areas that require immediate action, including transportation and accessibility, service access, the natural and built environment, local culture and identity, and urban marketing (urban potential and the image of the city).

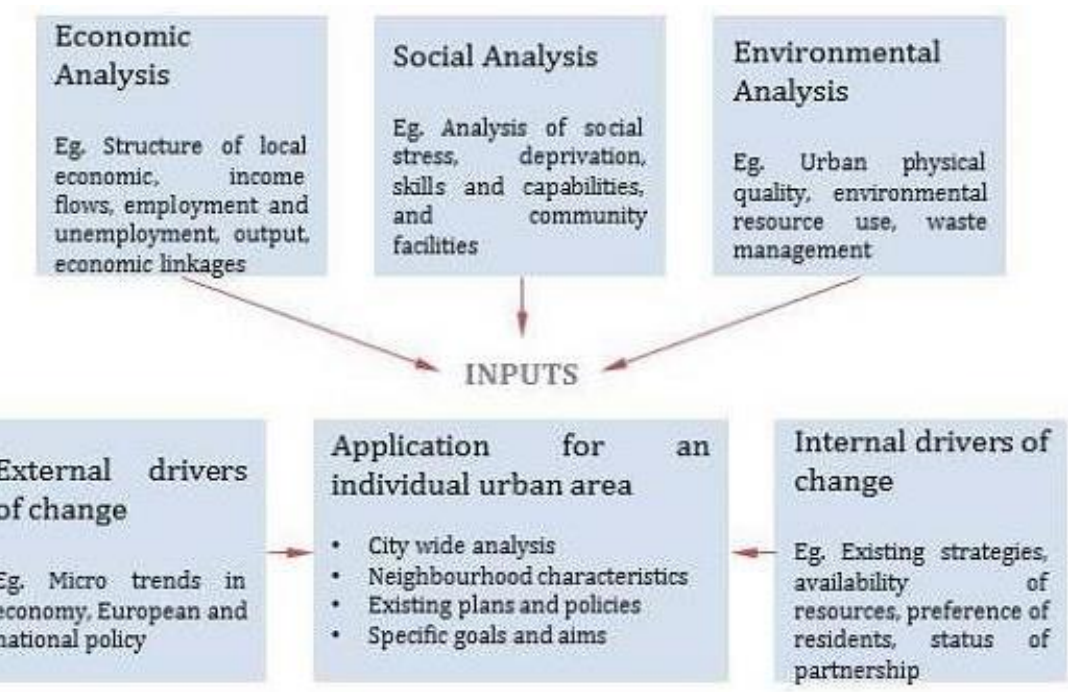

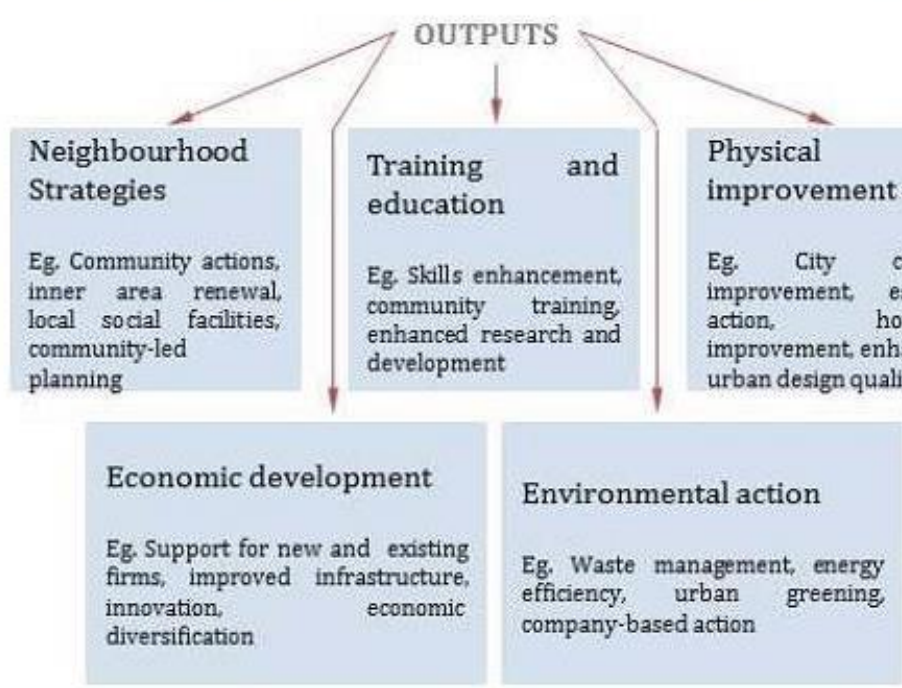

Fig. 1. The Urban Regeneration Process

Cities must collaborate with one another and preserve a strong link to rural areas. Additionally, cities must invest in long-term infrastructure to foster sustainable economic growth through the integration of the private and non-governmental sectors and the building of relationships with regional and national governments. As members of international urban networks, Romanian cities may benefit from the best practices of other cities and apply them to their own regeneration initiatives. Additionally, if Romanian cities' efforts are successful, they might serve as a model for other communities. 


\section{URBAN WATERFRONT REGENERATION}

This part is dedicated to a single type of urban environment: the urban coastline. The urban coastline has a distinct transformational history, which has resulted in a diversity of urban challenges. This section will define the urban coastline, discuss its historical relevance, and track the regeneration of urban shorelines.

Numerous historic settlements have cropped up along rivers and lakes' banks. According to Hoyle [10], "many coastal and riparian human towns owe their existence and success to water transport and trade, and such urban settlements and their ports have historically been functionally and spatially connected - from prehistoric times to the last decades." As Kostof [11] noted, the presence of cities around water bodies has a profound influence on the layout of the city and its future extension. Cities' proximity to water bodies had a significant impact on them, both in terms of shaping the character of the city and synchronizing its evolution with the growth of the sea shore. Numerous cities worldwide are associated to water sources, which, according to Breen and Rigby [12], has aided in their genesis, identity, and continued growth in many situations.

Urban coastlines may be evaluated from a variety of angles, including spatial, functional, and aesthetic. Hoyle's view of the urban coast was spatial, and he was particularly interested in the connection of the port and the city. He views the urban coast as a point of interaction between port and urban regions, or as a transition zone between port and urban land use [13]. According to Desfor et al. [14], the coast is a unique place where sea and land combine. "The coasts have historically been and continue to be areas where a variety of variables, both social and ecological, reflecting global, regional, and local forces, engage in furious struggles that reshape the metropolis," they said. Dovey's alternative concept [15] defined the shoreline as a border, a condition that separates the steady stripes of the city from the smooth flow of water. It is a spatial "between" situation that mediates a variety of dialectical oppositions - order / chaos; being / becoming; location / space; closed / open; solid / null [15]. However, these definitions give a philosophical sense of what comprises the beach rather than a practical understanding.

Breen and Rigby [16] elaborate on the urban seashore. "The urban shore" is described as "the water's edge in diverse cities." A seaside can be a river, a lake, an ocean, a bay, a stream, or a canal, but it can also be a wilderness refuge, a cargo port, or anything in between. As defined by Bruttomesso [17], the urban shoreline is a unique sort of linear urban boundary that connects the city to a large body of water. These two definitions were found suitable for this investigation. Breen and Rigby's definition is wider, including sites aesthetically or historically associated to water. Breen and Rigby's concept encompasses regions not just physically related to water, but also visually or historically.

\section{CONCLUSIONS}

The goal of this study was to give a foundation and backdrop for understanding the notions of urban transformation and regeneration. This paper has underlined the dynamic character of urban areas. It also spoke on the challenges of regeneration as a comprehensive approach to the interaction of various elements that influence and produce the urban environment. Furthermore, it is critical to acknowledge that existing urban regeneration practices are simply a stepping stone in the evolution of metropolitan zones.

As a consequence of the current challenges of transition and urban regeneration, new districts have emerged in many cities, providing fresh hope for the future. Waterfront areas 
have developed from abandoned industrial property or former port uses to locations that try to rehabilitate a city's image, repay global investment, and entice people back to the wilderness [29]. Despite the immense promise presented by coastal urban regeneration, communities face significant challenges. In their local and global settings, these concerns must be acknowledged and handled.

\section{REFERENCES}

[1] Roberts P. 2000. The Evolution, Definition and Purpose of Urban Regeneration In: Roberts P. \& Sykes, H. (eds.) Urban Regeneration: A Handbook. London: SAGE.

[2] Roberts, P. 2000. The Evolution, Definition and Purpose of Urban Regeneration London: SAGE.

[3] JEFFREY, P. \& POUNDER, J. 2000. Physical Environmental Aspects. In: ROBERTS, P. \& SYKES, H. (eds.) Urban Regeneration; A Handbook. London: SAGE.

[4] ROBERTS, P., STRUTHERS, T. \& SACKS, J. 1993. Managing the metropolis: metropolitan renaissance : new life for old city regions, Avebury.

[5] MCCARTHY, J. 2012. Partnership, Collaborative Planning and Urban Regeneration, Ashgate Publishing, Limited.

[6] TALLON, A. 2013. Urban Regeneration in the UK, Taylor \& Francis.

[7] LEARY, M. E. \& MCCARTHY, J. 2013. Companion to Urban Regeneration, Taylor \& Francis.

[8] ROBSON, B. T. 1988. Those Inner Cities: Reconciling the Economic and Social Aims of Urban Policy, Clarendon Press.

[9] PACIONE, M. 2009. Urban Geography: A Global Perspective, Taylor \& Francis.

[10] HOYLE, B. 2002. Urban waterfront revitalization in developing countries: the example of Zanzibar's Stone Town. Geographical Journal, 168, 141-162.

[11] KOSTOF, S., CASTILLO, G. \& TOBIAS, R. 1999. The city assembled: the elements of urban form through history, Thames and Hudson.

[12] BREEN, A. \& RIGBY, D. 1996. The New Waterfront; A World Urban Success Story, Singapore, Thames and Hudson.

[13] HOYLE, B. 1989. The port-City interface: Trends, problems and examples. Geoforum, 20, 429-435.

[14] DESFOR, G., LAIDLEY, J., STEVENS, Q. \& SCHUBERT, D. (eds.) 2010. Transforming urban waterfronts: fixity and flow: Taylor \& Francis.

[15] DOVEY, K. 2005. Fluid City; Transforming Melbourne's Urban Waterfront, Sydney, Australia UNSW Press.

[16] BREEN, A. \& RIGBY, D. 1994. Waterfronts: Cities Reclaim their Edge.

[17] BRUTTOMESSO, R. 2001. Complexity on the urban waterfront. Waterfronts in postindustrial cities, 39.

Note:

Nicolae-Costin Mociu - PhD, Ovidius University of Constanta, Bd. Mamaia nr. 124, 900356-Constanta, Romania (corresponding author to provide tel:+40722 246 057; e-mail: costin.mociu@365.univ-ovidius.ro) 